\title{
Socio-economic aspects of bank lending to agriculture
}

\author{
Anna I. Serebrennikova*, Aleksey V. Mikryukov, and Tatyana A. Tchilimova \\ Ural state University of Economics, 620144 Yekaterinburg, Russia
}

\begin{abstract}
The article is devoted to the socio-economic aspects of banks ' activities in relation to agricultural lending. The contextual background of the study is the social significance of agriculture for the country in terms of food security and the formation of a stable standard of living of the population. The purpose of the study was to reach the essential understanding of the social aspects of the Bank's activities by considering the social functions of the Bank in the lending process. The article considers the composition of credit subjects and gives a brief description of them. The activity of the State as a regulator of credit relations and a full participant in lending is emphasized. The essential understanding of the bank 's social functions in the context of solving the state 's social task of financing agriculture through the mechanism of concessional lending has been expanded. Conclusions are made about the leading role of the state in the formation of the mechanism of interaction between the Bank and the borrower with the strengthening of social functions of the Bank.
\end{abstract}

\section{Introduction}

Agriculture is an integral part of the economy of almost all countries and the global economy. Sustainable development of the world economy is directly dependent on solving the problem of food security, which is achieved through the construction of productive and sustainable agricultural systems to provide the population with food [1].

Food security issues are considered both at the international level and at the level of individual States. For a particular State, these issues acquire special significance, which increases during periods of increasing international tension, the introduction of economic and political sanctions against a State or a group of States, economic and political crises, economic destabilization, etc. Food security, along with financial and economic security, are elements of national security, which makes it necessary to consider them in close relationship. Food security is considered by researchers not only as a component of economic security of the State, reflecting national interests in the field of expanded reproduction of agricultural products, but also as a condition for ensuring a stable standard of living for the population [2].

Based on this, it is obvious that the agricultural sector can be classified as an economically and socially significant area.

\footnotetext{
*Corresponding author: serebrennikova_ai@usue.ru
} 
An increase in agricultural production can only be realized on the basis of expanded reproduction, as in other sectors of the economy. In the modern economy, extended reproduction cannot be fully provided at the expense of enterprises ' own funds, which makes producers use additional attracted sources of financing, the volume and share of which are steadily growing [3, 4]. The traditional, most accessible and operational source of attracted resources is a Bank loan. A Bank loan can be used both to replenish the company's defense assets, which is justified by the seasonal nature of its activities [5], and to replenish fixed assets. The social significance of agriculture and its crediting is confirmed by the active role played by the state in regulating the activities of agricultural producers and their crediting.

According to the authors, the social component that occurs when banks lend to agricultural producers is not currently given sufficient attention. The authors believe that the social component in the process of Bank lending to agricultural enterprises should only be strengthened due to the Bank's social functions.

Based on the above, the purpose of this study was to deepen the essential understanding of the social component of banks ' activities in the process of lending to agricultural enterprises.

The goal is achieved by solving the following tasks:

- identify the characteristics of subjects of lending to agricultural enterprises;

- expand the understanding of the essence of the Bank's social functions;

- determine the significance of State regulation of agricultural lending.

\section{Materials and Methods}

Currently, a large number of studies by domestic and foreign authors are devoted to the state, problems and availability of loans to agricultural producers, especially in developing economies [6, 7, 8, 9, etc.]. Agricultural lending has features, accompanied by specific risks, and coupled with the features and problems of lending [10, 11, 12, 8, 6 etc.].

For most countries, including economically developed ones, agriculture is a subsidized sector and requires government participation in one form or another. Based on this, the issues of lending are considered along with the government activities to regulate agriculture, including through the development of the credit system $[5,13,14,10,15,16]$.

During the research the authors relied on works devoted to bank lending to agriculture in various areas, including preferential, and its current state [6, 14, 3, 12, 4].

When performing the presented research, the authors based on a wide range of general scientific research methods: observation, abstraction, induction, deduction, generalization, etc.

\section{Results and Discussion}

The consideration of agricultural lending should begin with a general understanding of the lending entity. The authors share the view that when lending to agricultural producers, three equal participants in the lending process are identified: borrower, regulator and potential creditors [10]. The equality of these lending entities consists in equal responsibility for the final result of lending and the impossibility of implementing a full credit process without the participation of all parties. Let us give a brief description of lending entities.

Borrower. The borrowers are enterprises of various forms of ownership that produce agricultural products. A characteristic feature of domestic agriculture is its multiplicity [6], which leads to differences in the credit attractiveness of economic entities for creditors. 
Regulator. The authors consider the most important point in identifying the regulator assigned to the State as a direct participant in lending. In modern conditions, agricultural financing processes, as a rule, cannot do without direct or indirect State participation [10], which emphasizes the special economic and social significance of agricultural lending. In fact, we can talk about a special type of agro loan, which has increased social significance. As noted above, government regulation is present in most countries, regardless of their level of economic development, and has a strong social focus. For example, in a number of countries, banks are required to provide financial services, including loans, to agricultural enterprises that are considered socially priority [14]. One of the main directions of the European research and innovation program "Horizon 2020" was the solution of socially significant problems in the field of health, agriculture, etc. To solve social problems, 35.8 billion euros were allocated from the total budget of 80 billion euros [13]. This puts social tasks on a par with the tasks of creating advanced science and gaining leadership in industrial development. There is a rather large number of examples of State participation in financing agriculture. At the same time, a variety of forms of state economic support and regulation of agriculture is noteworthy.

Note that for most countries, as well as for Russia, state regulation is an objective necessity dictated by the specifics and high risks of agricultural production. For Russia, this need is exacerbated by a chronic lack of financial support for agriculture, which leads to the moral and material obsolescence of fixed assets and a shortage of working capital. The need for agricultural financing exceeds the possible resources of the State that can be allocated to producers. A natural solution in this situation was to use the capabilities of the banking system. In Russia, a scheme of credit and financial support was created to encourage expanded reproduction in agriculture. The main element of the scheme is concessional lending, implemented through commercial banks. The mechanism for implementing preferential lending is established by the "Rules for granting subsidies from the Federal budget to Russian credit organizations for the reimbursement of lost income on loans issued to agricultural producers, organizations and individual entrepreneurs engaged in the production, primary and (or) subsequent (industrial) processing of agricultural products and their implementation at a preferential rate", approved by the decree of the Government of the Russian Federation dated December 29, 2016, No. 1528. The scheme involves obtaining preferential loans to agricultural enterprises through commercial banks at a preferential rate with further transfer of the subsidy directly to the Bank that issued the loan. Thus, the scheme excludes the payment of the full loan rate by the enterprise and the expectation of payment of a subsidy for the reimbursement of these expenses. In essence, the Bank becomes a kind of lender to the State, providing a loan at a preferential rate and expecting for reimbursement of lost profits. Introducing this scheme, the State not only provides farmers with preferential loans, but also uses the capabilities of banks.

Potential lender. Credit institutions, including commercial banks, can act as creditors. However, of all credit institutions, only banks have the funds necessary for lending, and extensive experience in its organization based on the provision of Bank credit products. This state of affairs is a consequence of the role played by banks as financial intermediaries, attracting and redistributing temporarily available financial resources, which the state uses when banks are included in the preferential lending mechanism, thereby partially solving the problem of limited financial resources.

For better understanding the role of banks in agricultural lending, we turn to the economic and social functions they perform. Social functions are closely related to economic functions and are of particular interest in the light of lending, such a socially important sphere as agriculture, and government participation in this process. The authors are of the opinion that banks have two complex synthetic functions: 
- to provide economic entities with the money necessary for current settlements and payments, as well as for economic development;

- providing economic entities with specific banking products [17].

The above functions make it possible to conclude that the activities of the bank are inseparable from its customers, which are society. The Bank's activity is to meet the financial needs of its clients, which are not only financial, but also social. Customer needs are met by providing the final result of the Bank's activities - a banking product. Based on this, the Bank's activities can be considered not only as economic, but also as social ones. In the case of servicing agricultural enterprises by the Bank, the social orientation of its activities is significantly enhanced. The loan product provided by the Bank in this situation meets both the financial need of a particular agricultural producer and the social need for the development of agriculture as a whole.

In addition to economic functions, banks also implement social functions, which include the protective, regulatory, behavioral, and social elevator functions [18].

As a rule, the implementation of the security function is associated with the Bank's guarantee of the safety of attracted funds and the continuity of income payments to clients. The authors consider it possible to extend the interpretation of the function by guaranteeing the terms of the banking product that meet the needs of the client. Such a guarantee of conditions becomes natural with the maximum orientation of the bank's activities to the customer in the face of increased competition in the banking products market and the formation of the buyer's market. Returning to Bank lending to agriculture, we note that the State acts as an additional guarantor of acceptable credit conditions for the client. The authors see the extension of the protective function in protecting the interests of not only clients, but also the State, which is manifested in checking the borrower's compliance with the requirements for granting preferential loans.

Regulatory and behavioral function is manifested in the possibility of influencing the behavior of the borrower using a banking product that has certain parameters. In particular, the establishment of requirements for enterprises applying for preferential credit can expand the range of such enterprises, contributing to the solution of social problems of the State. It is obvious that only the coincidence of the interests of all subjects of credit relations (expressed in the terms of the banking product) can bring the Bank closer to the fullest implementation of its social functions.

The function of a social elevator is usually interpreted as the availability of banking products for an individual in order to improve their educational level. Improving the level of education and skills of personnel in rural areas allows us to solve the issue of personnel starvation in agriculture. The authors draw attention to the direct dependence of the loan amount on the borrower's income level, which allows us to expand the interpretation of the function. Increasing the income of agricultural enterprises that are being credited will lead to an increase in the level of income of employees, and, consequently, the availability of Bank credit products and educational services for them.

Despite the presence of economic and social functions in the Bank's activities that allow realizing the common interests of all lending subjects, the growth rate of Bank lending to agriculture remains low. Most researchers refer to the unattractiveness of the industry for lenders due to its features: seasonal nature, long production cycle, probabilistic nature of production and the presence of specific risks, low profitability, etc. $[10,11,12$, etc.]. The authors of the article consider it necessary to study the features of agriculture in order to take them into account when developing the parameters of loan products. However, the reasons for undeveloped Bank lending to agriculture are seen in the state of the financial market, as well as the undeveloped market mechanisms. The excess of the level of profitability of the financial sector over the yield in the real economy and agriculture in 
particular makes it almost impossible to develop a banking product that can meet the needs of all lending entities. The presence of State credit entities contributes not only to the maintenance of agriculture as a socially important sector, but also the formation of new mechanisms of credit interaction between the Bank and the borrower, contributing to a more complete implementation of its functions by the Bank, including social ones.

\section{Conclusions}

The development of agriculture in the country is of great social importance in terms of ensuring food security and maintaining a stable standard of living for the country's population. Extended progressive development of the agricultural sector is impossible without providing additional funding. The participation of the State in the regulation of agriculture and its financing confirms the social significance and necessity of agricultural development.

The most likely and acceptable option for financing agriculture is Bank lending. Consideration of the interaction of entities in the process of lending to agriculture allows you to deepen the idea of the socio-economic nature of banks, based on the existence of social functions of the Bank directly related to its economic functions. Expanding the understanding of the essence of the bank's social functions in the context of agricultural lending leads to the conclusion that there is a potential opportunity to reach a consensus between the Bank and the borrower at the level of the banking product.

The reason for the underdevelopment of Bank lending to agriculture is the imbalance in the development of market segments and the lack of effective market mechanisms for regulating it at the present stage. The leading role in the development of agricultural financing belongs to the State, which should be considered as a real subject of lending. The State's efforts to create a mechanism for preferential lending have not only made it possible to increase the availability of loans for agricultural producers, but also to use the resources and experience of banks in lending, stimulating the creation of new banking products that show the social component of banks ' activities.

\section{References}

1. V.G. Egorov, E.V. Shavina, A.V. Kuznetsov, Innovation and Investment, 9, 295 (2019)

2. R.A. Nabiev, R.S. Aseinov, The development strategy of the agro-industrial complex of Russia in the context of ensuring food security, (2004)

3. V. Maslova, Agribusiness: Economics, Management, 12, 41-47 (2014)

4. L.Kh. Tlatova, N.P. Donskaya, R.I. Khugaeva, Proceedings of the Mountain State Agrarian University, 4, 330 (2015)

5. L.G. Volkova, Bulletin of the Michurinsk State Agrarian University, 4, 117 (2015)

6. O.V. Isaeva, A. A. Udalov, Bulletin of the Don State Agrarian University, 1-2, 75 (2019)

7. G. Lych, V. Chabatul, A. Bashko, M. Papinova, Agricultural Economics, 8, 34 (2019)

8. Yu.A. Lebedeva, Problems and prospects of lending to the agricultural industry in the Russian Federation, Law, Economics and Management: Topical Issues Proceedings of the All-Russian Scientific and Practical Conference with International Participation, 34 (2019)

9. Erdogan Gunes, Hormoz Movassaghi, Int. J. of Applied Agricultural Sciences, 3, 123 (2017) 
10. T.G. Kardailskaya, Business. Education. Right. Bulletin of the Volgograd Institute of Business, 2, 197 (2012)

11. A.S. Zvonorenko, Business. Education. Right. Bulletin of the Volgograd Institute of Business, 2, 212 (2014)

12. I.V. Ivanyuk, N.V. Tertychnaya, Bulletin of the Voronezh State Agrarian University, 4, $153(2015)$

13. E.B. Lenchuk, Problems of Forecasting, 3, 132 (2016)

14. O.V. Novikova, Bulletin of Altai State Agrarian University, 2, 165 (2015)

15. R.S. Aloyan, Lending as a factor in regulating the problems of the agricultural sector of the Republic of Armenia, Innovative research: theory, methodology, practice, collection of articles of the XVI International Scientific and Practical Conference, 182 (2019)

16. A.V. Papushkina, State regulation of the agro-industrial complex through the credit system, Economics, management and law: innovative problem solving, Collection of articles of the XVIII International Scientific and Practical Conference, 9 (2019)

17. A.M. Tavasiev, Banking (2015)

18. L.V. Krylova, Labor and Social Relations, 6, 34 (2015) 